\title{
The Role of Higher Order Thinking Skills in Green Skill Development
}

\author{
Yee Mei Heong ${ }^{1}$, Lai Chee Sern ${ }^{1}$, Tee Tze Kiong ${ }^{2}$ and Mimi Mohaffyza Binti Mohamad ${ }^{1}$ \\ ${ }^{1}$ Universiti Tun Hussein Onn Malaysia, Faculty of Technical and Vocational Education, Department of Engineering Education, 86400 \\ Parit Raja, Batu Pahat, Johor, Malaysia \\ ${ }^{2}$ Universiti Pendidikan Sultan Idris, Faculty of Technical and Vocational Education, 35900 Tanjong Malim, Perak.
}

\begin{abstract}
In the era of rapid development, industries sector will bring negative effect of environment. Therefore, green technologies should be exposed in education system for transforming economy model to greener economy modal. HOTS should be applied in green skill development in order to solve problems, generate new products and ideas. The application of HOTS can enhance someone in processing new information for various alternatives, ideas, actions, and design solutions to solve a problemIn this regard, a study on the role of Marzano HOTS in green skill development has been designed for the above purpose. This article suggests an initial idea of the study. The key elements identified in green skills development include green economy, green industry and green skills. Meanwhile, elements related to the Marzano HOTS is comparing, classifying, induction, deduction, error analysis, constructing support, abstracting and analyzing perspectives. As conclucion, HOTS requires someone to critically evaluate information, make inferences, and make generalizations. With HOTS, we enable to apply knowledge, skills and values to make reasoning and reflection to solve problems, make decisions, innovate and strive to create something in green skills development.
\end{abstract}

\section{Introduction}

The problems related to environment pollution will bring about devastating consequences such as rising sea level, extreme droughts or monsoons, and changing weather pattern [1]. These consequences will negatively affect the sustainability of social and economic activities across the world.

In order to deal with the environmental issues, governmental bodies as well as private sectors have to work hand in hand to ensure the sustainability of the social, economic, and environment development. For instance, the Malaysian government has announced that one of the primary components under the $11^{\text {th }}$ Malaysian Plan 2016-2010 (11MP) is to pursue green growth for sustainability and resilience which aims at achieving a resilient, low-carbon, and resource-efficient economy model that leads to higher living quality, more conducive living environment, and sustainable living condition [2]. In addition, governmental agencies should come out with more efficient policies and the enforcement of rules and regulations related to environmental conservation must be strengthened. In this aspect, the European Union (EU) has developed the "EU 2020 strategies" which targets to elevate the consumption of renewable energy and reduce greenhouse gas emission within EU member countries [3]

Some developed countries, such as Japan and Germany, have taken pragmatic long-term approach to mitigate the environmental problems by transforming the existing economy model to a more environmental friendly and greener economy model [4]. The industries that are less environmental friendly and less energy efficient are now moving towards to those that are less polluting and more efficient. For example, the manufacturing processes produce lower carbon emissions and consume less unrenewable energy.

The transformation of economy model to a greener model is increasing the pace of change in manpower market. The green industry has created some entirely new green jobs (e.g., energy auditor) and "greening" the existing jobs in the industries. For instance, in automobile industry, engineers require green skills to work with fuel efficient technologies; and an architect needs green skills to integrate natural elements into building design.

The change of skill requirements is pervasive and it calls for a huge effort to revise the training programmes. The training institutions should embed "green" elements into the training curricula. Students should be exposed to green technologies during the training. In addition, higher order thinking skills (HOTS) should be taught to the students because the nature of the green jobs is dealing with problem solving and create new green technologies, products or ideas. For instance, how to reduce energy consumption, and how to reduce environmental pollution.

Before HOTS is further discussed, the concepts of green economy, green industry, and green skills will be presented in the following sections in order to provide some general insights to the readers. 


\section{Concepts of green economy, green industry, and green skill}

\subsection{Green economy}

A green economy can be considered as an economy model for sustainable development as it promotes advancement and sustainability in terms of social, economy, and environment.

Many definitions have been put forward by a number of organisations based on different research works and different target audiences. For example, United Nation Environment Program (UNEP) defines green economy as an economy model that is socially inclusive, low carbon, and energy resource efficient that significantly cuts down environmental risks and substantially improves social well-being [4]. Additionally, the green economy which is supported public and private investment will bring growth in employment and income and at the same time reduce pollution, enhance energy and resource efficiency, and promote biodiversity and ecosystem conservation.

Apart from UNEP, United Nations Conference on Trade and Development (UNCTAD) defines green economy as follows [5]:

\begin{abstract}
An economy that results in improved human well-being and reduced inequalities, while not exposing future generations to significant environmental risks and ecological scarcities. It seeks to bring long-term societal benefits to short-term activities aimed at mitigating environmental risks. A green economy is an enabling component of the overarching goal of sustainable development.
\end{abstract}

(page IV)

This definition puts the focus on sustainable development that emphasizes environmental conservation and protection for the sake of next generation.

In addition to the above definitions, Green Economy Coalition (GEC) also provides a brief concept of green economy. According to GEC, green economy can be defined as a resilient economy that provides better quality of life for all within the ecological limits of the planets [6].

Green economy has been defined differently by different agencies. However, two elements have been mentioned in all those definitions, namely, "nature conservation and environmental protection" and "human well-being improvement and social development". Taken together, green economy can be conceptualised as an economy model which emphasises nature conservation and environmental protection that leads to improved human well-being and sustainable social development.

\subsection{Green industry}

Green economy will bring sustainable development in social and economy without affecting the environment. Supports and cooperation from industries are required in order to achieve the sustainable development. Industries should opt for a more sustainable partway of growth by undertaking environmentally friendly investments.

According to Schwerzer [7], can be any industry that involves in production, distribution, and/or services which emphasises the aspects of environmental protection and nature conservation. In general, green industry is usually related to fields of renewable energy, green building, fuel efficient transportation, recycling, forestry, and ecotourism. For example, recycling companies is one of the green industries as its nature of business is promoting environmentally friendly living condition. Likewise, solar panel production company, power generation companies that utilise renewable energy, construction companies that apply eco-friendly concept in design and building construction can also be categorised as green industries.

Green industries create green jobs. Green jobs can be any jobs pertaining to business that produce goods or provide services that benefit the environment and conserve natural resources. Additionally, green job also can be regarded as jobs that aims at reducing natural resources consumption or making the production more environmentally friendly [8].

Hard and soft skills are no more sufficient for an individual to secure a job especially green job. Therefore, workers must equipped themselves with green skills in order to help them secure a green job.

\subsection{Green skill}

Green skill is referred to as skill for sustainable development. According to [9], green skills are regarded as skills for sustainability which are related to the technical skills, knowledge, values and attitudes needed in the workforce to develop and support sustainable social, economic and environmental outcomes in business, industry and the community. Likewise, CEDEFOP defines green skills as the knowledge, abilities, values and attitudes needed to live in, develop and support a society which reduces the impact of human activity on the environment [10]. Taken together, green skills is generally composed of three dimensions, namely, knowledge (cognitive dimension), skills/abilities (psychomotor dimension), and attitudes/values (affective dimension) needed by workers to promote sustainable development in social, economy, and environment. From the cognitive dimension, the knowledge concerning environmental protection can be regarded as an element of green skills. From psychomotor perspective, green skill refer to the ability to, for instance, minimise energy consumption, or reduce greenhouse gases. Green skills also refer to affective aspect, for example, motivation of an individual to conserve natural resources.

In most cases, the new jobs created by the green industries will require a mix of both traditional and new green skills. For example, construction companies that carry out building and housing projects will require workers with traditional construction skills and up-to-date training in energy efficiency [11]. In general, it can be said that for low to middle-skilled jobs, there will be a need for traditional skills complemented by green skills, 
most of which can be offered by on-the-job training programmes. Higher skilled occupations, such as those found in eco-consulting, will require a broader and more specific set of new green skills. Such new skills are best delivered by educational and in-depth training programmes which involve higher order thinking skills.

\section{Higher Order Thinking Skills (HOTS)}

In the 21 st century, thinking skills especially creativity is crucial in order to support economic prosperity. Human creativity has become a major economic resource [12]. Industries of the 21 st century will increasingly depend on the generation of knowledge through creativity and innovation [13]. Employers often suggest the importance of students to be equipped with skills to make decisions and think critically and creatively before entering the working world.

In addition, the increase in labor productivity also depends on the quality of each individual's talent, namely creativity [14]. Creativity and innovation are important keys to success in any field in this era of rapid development [15]. This is so because business management activities such as processes to increase productivity, solve problems, motivate employees, make decisions and rapid technological change are in dire need of creative ideas. Idea generation thus, is a crucial part in resolving a problem [16].

Reference [17] defines idea as a basic element of thought which can be visual, concrete, or abstract. Idea is all stages of the cycle of abstract thinking [18] and it also can be visualized in our mind. Reference [19] and [20] categorized the generation of ideas as a higher order thinking skills (HOTS) activities that require high level creative thinking and action.

However, not everyone is able to generate good ideas because ideas cannot be generated easily. Idea generation occurs in our brain through the cognitive, metacognitive, chemical and biological process [19]. Hence, complex thinking skills such as problems solving, creating, analyzing, evaluating and others are needed to process the collected information [21]-[22] for generating an idea.

HOTS is one component of the creative thinking skills and critical thinking. According to [23], creative thinking can develop individual to be more innovative, have good creativity, ideal and imaginative. When we know how to use both of these skills, it means that we have applied HOTS. Everyone is capable to think, but most of them need to be encouraged, taught and assisted to the higher order thinking processes.

These HOTS are teachable and learnable. Everyone has the right to learn and apply thinking skills, just like other disciplines of knowledge. Optimal use of thinking skills involve HOTS as the skills to analyze, synthesize, evaluate, and create them [24]. Higher order thinking is defined as the expanded use of the mind to meet new challenges [25]. It requires someone to apply new information or prior knowledge and manipulate the information to reach possible answer in new situation [26]-[28].
HOTS allows someone should be able to do a comparison, evaluation, justification and make inferences [29]. HOTS transformation process will happen when students combine facts and ideas through the ability to synthesize, generalize, explain, hypothesize, or produce conclusions and interpretations [30]. The process of manipulating information and ideas will enable students to solve problems, find understanding and gain new insights in learning [24].

A question to be answered or a problem to be solved cannot be done through routine application of previously acquired knowledge [31]. But it can be solved only when expanded use of mind occurred that a person must interpret, analyze or manipulate information. This is because higher order thinking is characterized as non algorithmic, complex, self regulative, meaningful, effortful and providing multiple solutions, nuanced judgments, multiple criteria and uncertainty [32]. HOTS is an imperatives aspect in green skill development.

\section{Marzano higher order thinking skills}

Marzano's research on thinking skills is important to students and educators in higher education institution primarily. Marzano identifies eight HOTS, namely comparing, classifying, inducing, deducing, error analysis, constructing supporting, analyzing perspectives, and abstracting, which work within the Dimensions of Learning (1992) framework. The Dimensions of Learning model assumes that the process of learning involves the interaction of the following five types of thinking:

(i) positive attitudes and perceptions about learning

(ii) thinking involved in acquiring and integrating knowledge

(iii) thinking involved in extending and refining knowledge

(iv) thinking involved in using knowledge meaningfully (v) productive habits of mind

Marzano's Dimensions of Learning is a comprehensive model that uses what researchers and theorists know about learning to define the learning process. Dimensions of Learning offer a way of thinking about the extremely complex process of learning so that study can be attended to each aspect and gain insights into how they interact. The five types of thinking are premised as five dimensions of learning that are essential to successful learning [33]. The Dimensions framework will help us to

- Maintain a focus on learning;

- Study the learning process; and

- Plan curriculum, instruction, and assessment that takes into account the five critical aspects of learning.

These 8 higher order thinking skills are identified in Dimension 3 which will help students extend and refine knowledge. The most effective learning occurs when we use knowledge to perform meaningful task. 
Table 1. The definition of five Marzano HOTS

\begin{tabular}{|c|l|}
\hline Marzano HOTS & \multicolumn{1}{|c|}{ Definition } \\
\hline comparing & $\begin{array}{l}\text { Identifying and articulating } \\
\text { similarities and differences among } \\
\text { items. }\end{array}$ \\
\hline classifying & $\begin{array}{l}\text { Grouping things into definable } \\
\text { categories on the basis of their } \\
\text { attributes. }\end{array}$ \\
\hline $\begin{array}{c}\text { inductive } \\
\text { reasoning }\end{array}$ & $\begin{array}{l}\text { Inferring unknown generalization or } \\
\text { principles from information or } \\
\text { observation. }\end{array}$ \\
\hline $\begin{array}{c}\text { deductive } \\
\text { reasoning }\end{array}$ & $\begin{array}{l}\text { Using generalization and principles to } \\
\text { infer unstated conclusion about } \\
\text { specific information or situations. }\end{array}$ \\
\hline $\begin{array}{c}\text { analyzing errors } \\
\text { constructing } \\
\text { support }\end{array}$ & $\begin{array}{l}\text { Identifying and articulating error in } \\
\text { thinking. }\end{array}$ \\
\hline $\begin{array}{l}\text { Building system of support for } \\
\text { assertions. }\end{array}$ \\
\hline $\begin{array}{c}\text { analyzing } \\
\text { perspectives }\end{array}$ & $\begin{array}{l}\text { Identifying multiple perspectives on } \\
\text { an issue and examining the reasons or } \\
\text { logic behind each. }\end{array}$ \\
\hline $\begin{array}{l}\text { abstracting } \\
\text { undentifying and articulating the } \\
\text { information. }\end{array}$ \\
\hline
\end{tabular}

\section{The role of Marzano HOTS}

Marzano HOTS selected for this study because HOTS model has clear description of the process of the eight HOTS. Marzano HOTS has four major components that comprise the definitions, procedures, thinking tools and assessment (Fig. 1). All eight KBAT Marzano has four components. The first component describes the definition so that students clear on the function, characteristics and use of each HOTS. After knowing the definition, the step of using every HOTS are also described in the procedure with questioning technique.

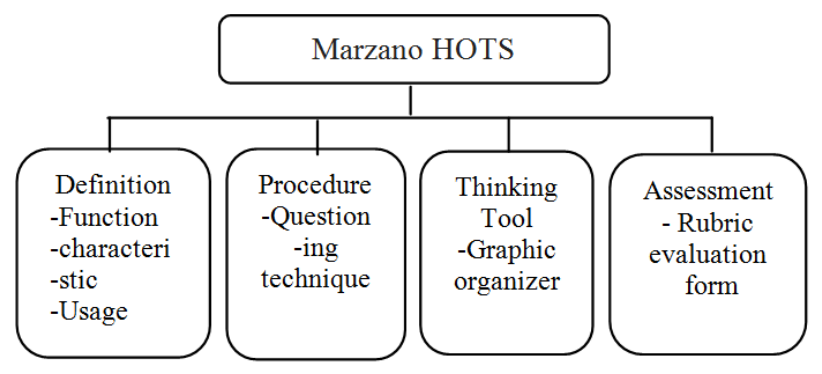

Figure 1. The main components of Marzano HOTS.

Questioning technique is used for probing questions to get information in every step of the process HOTS. Use of this technique allows students to observe the thinking process actively and to think reflectively (Othman \& Rahman, 2011). In addition, this technique can also trigger and enhance students' thinking (Solomon et al., 2011) to analyze and reason in a more systematic and effective (Tee et al., 2010b).
This model also provides a thinking tool namely graphic organizer. Graphic organizer appropriate and relevant to the students recorded their thoughts. It's a form of illustration or sketch that was used for the purpose of planning, organizing, researching, analyzing or thinking of ideas to produce something more systematic, clear and effective (Solomon et al., 2011). By using graphic organizer, students can not only see the process of thinking through concrete and explicit, but also be able to think and process information actively (Othman \& Rahman, 2011). So, applying HOTS will be more effective.

In the meantime, the thinking tool and thinking skills are essential and indispensable in solving problem and creating idea process so that students can make judgments and decisions wisely (Caviglioli, Harris \& Tindall, 2002; Splitter \& Sharp, 1995). The advantages of the combined use of questioning technique and graphic organizer in the long term allows students who have a tendency to accept information for concrete (Concrete perceivers) became more abstract (abstract perceivers) (McCarthy, 1987).

Finally, after adopting the HOTS, all thoughts were listed in graphic organizer and rated based on the rubric evaluation form. Rubric is an assessment tool that lists the criteria for a work to score in good rate (Andrade, 1997). Rubric serves to identify the level of student applying HOTS (Peirce, 2006) on problems solving and generating ideas. Each HOTS have their evaluation form. The evaluation criteria in the evaluation form is based on the steps of each process HOTS. With the four clear and systematic components, application of all HOTS become stronger and more organized.

\section{Conclusion}

Each student must take the initiative to improve the quality of thinking and to foster a positive attitude in developing green skill for any industries. If the industries know how to use the correct thinking skill such as how to take effective action and make the right decision for solving problem, so the industries must be able to obtain excellent solution in protecting environment. Through HOTS and problem solving, idea will become real when industries solve a problem (Mohd Radzi, 2010). To stimulate someone thinking, they must be given the opportunity to respond to the high-level questions. The use of more challenging high level questions will encourage someone to express opinions, make decisions, to find a solution to a problem, or to generate new ideas on matters relating to the content of education (Tee, 2012).

\section{Acknowledgment}

The authors would like to thank the Ministry of Higher Education, Malaysia for supporting this research under the Research Acculturation Grant Scheme (RAGS) vot no. RO51. 


\section{References}

1. M. E. Mousavi, J. L. Irish, A. E. Frey, F. Olivera, \& B. L. Edge, Climatic Change, 104(3-4), pp. 575-597 (2011)

2. A. Asohan, Digital News Asia. (2015, Mei 21). Retrieved from https:/www.digitalnewsasia.com/digitaleconomy/11 th-malaysia-plan-broadband-gets-somelove

3. CEDEFOP. Skills for Green Jobs: European Synthesis Report. (2010)

4. UNEP, UNEP Year Book: emerging issues in our global environment. 2011. Retrieved from www.unep.org/yearbook/2011

5. UNCTAD. UNCTAD Annual Report. 2011. Retrieved from http://unctad.org/en/PublicationsLibrary/dom2012d1 en.pdf

6. GEC. Green economy: an analysis of the UNCSD submissions. 2012 Retrieved from: http://www.greeneconomycoalition.org/document/gr een-economy-analysis-uncsd-submissions

7. J. Schwarzer. Industrial Policy for a Green Economy, (2013)

8. D. G., De Silva, T. P., Hubbard, R. P, McComb, \& A. $\mathrm{P}$. Schiller, Entry, growth, and survival in the green industry. 2011. Retrieved from: http://mpra.ub.unimuenchen.de/34412/

9. G., McDonald, L. Condon, \& M. Riordan, The Australian Green Skills Agreement: Policy and Industry Context, Institutional Response and Green Skills Delivery, (2012)

10. CEDEFOP. Green skills and environmental awareness in vocational education and training: Synthesis Report, (2012)

11. Apollo Alliance. Green-Collar Jobs in America's Cities. (2008)

12. R. Florida, The Rise of the Creative Class. And How It's Transforming Work. Leisure and Everyday Life. Basic Books, (2002)

13. The Third Outline Perspective Plan. Prime Minister April 2001.

14. B .Ario. Managing Creativity in the Workplace: Using Creativity of Your Workers. Associated Content, (2006)

15. K. J. Wheelihan. Creativity for Success, The Creativity Institute, 2011, Retrieved from: http://EzineArticles.com/

16. Sharp, A. (2008). Generating Ideas is an Important Part of Creative Problem Solving

17. B. Jonson. Design Ideation: The Conceptual Sketch in the Digital Age. Design Studies, 26 (6), 613-624, (2005)

18. D. Graham \& T. Bachmann. Ideation: The Birth and Death of Ideas. John Wiley and Sons Inc. (2004)
19. M. A. Abd Hamid. Pengenalan Pemikiran Kritis \&Kreatif. Skudai, Johor, Universiti Teknologi Malaysia, Cetakan pertama. (2001)

20. B. K. Beyer. Practical Strategies for the Teaching of Thinking. London: Allyn and Bacon, Inc. (1992)

21. A. R. Abd. Rashid. Falsafah Budaya dalam Pendidikan. Kuala Lumpur: Penerbit Universiti Malaya, (2003)

22. R. E. Meyer. Rotes Versus Meaningful Learning, Theory into Practice, 41 (4), 226-232, (2002)

23. S. H. Poh, "Kemahiran Berfikir Secara Kritis dan Kreatif," 2nd Ed, Kuala Lumpur: Kumpulan Budiman Sdn. Bhd, (2000)

24. L. W. Anderson, D. R. Krathwohl, P. W. Airasian, K. A. Cruikshank, R. E. Mayer, P. R. Pintrich, J. Raths, M. C. Wittrock. A Taxonomy for Learning, Teaching, and Assessing: A Revision of Bloom's Taxonomy of Educational Objectives. New York : Longman, (2001)

25. N. S. Rajendran, "Teaching and Acquiring HigherOrder Thinking Skills Theory \& Practice," Tanjong Malim Perak: Penerbit Universiti Pendidikan Sultan Idris, (2008)

26. S. Z. Mohamed, "Kesan Pendekatan Penyebatian Kemahiran Berfikir Kreatif Dalam Pengajaran Karangan Deskriptif Dan Karangan Imaginatif Dalam Kalangan Pelajar Tingkatan IV," Universiti Sains Malaysia: Disertasi PhD, (2006)

27. J. Ea, A. Chang, and O. S. Tan, "Thinking about Thinking: What Educators Need to Know," Singapore: National Institute of Education, Nanyang Technological University, McGrawltill Education, pp. $72,(2005)$

28. A. Lewis, and D. Smith, "Defining Higher Order Thinking. Theory Into Practice," 32, 131-137, 1993.

29. G. Sykes, R. Floden, \& C. Wheeler. Improving Teacher Learning in Thailand : Analysis and Options. Bangkok : The National Educational Commission. (1997)

30. T. K. Tee. Pengintegrasian Kemahiran Berfikir dan Peta Minda Buzan Bagi Penguasaan Kemahiran Berfikir Aras Tinggi. Universiti Tun Hussein Onn Malaysia: Tesis Ph.D. (2012)

31. F. M. Newmann, "Higher Order Thinking In Teaching Social Studies: A Rationale for The Assessment of Classroom Thoughtfulness," Journal of Curriculum Studies, 22, 41-56, (1990)

32. L. B. Resnick, "Education and Learning to Think," Washington, DC: National Academy Press, (1987)

33. R. J. Marzano, D. J. Pickering, D. E. Arredondo, G. J. Blackburn, R. S Brandt, C. A. Moffett, D. E. Paynter, J. E. Pollock, and J. S. Whisler, "Dimension of Learning Trainer's Manual," 2nd Ed, Aurora, Colorado: McREL, (1997) 